\title{
An Empirical Test of the Propositions by Gray and Tannen Relating to Gender Communication in Malaysia
}

\author{
Kamarul Zaman Ahmad ${ }^{1}$ \\ ${ }^{1}$ College of Business Administration, Abu Dhabi University, Abu Dhabi, United Arab Emirates \\ Correspondence: Kamarul Zaman Ahmad, College of Business Administration, Abu Dhabi University, Abu \\ Dhabi, PO Box 59911, United Arab Emirates. E-mail: drkamphd@yahoo.com
}

Received: November 27, 2011 Accepted: May 28, 2012 Online Published: August 30, 2012

doi:10.5539/ass.v8n11p250

URL: http://dx.doi.org/10.5539/ass.v8n11p250

\begin{abstract}
Purpose: This research tests the propositions relating to gender communication by Gray (1992, 2002) in his two books titled "Men are from Mars, Women are from Venus" and "Mars and Venus in the Workplace" and a third book written by Tannen (1990) "You just don't understand: Women and Men in Conversation." These three books have been the source of gender-related controversy since their publication. Design/methodology/approach: The questionnaire was divided into three parts and contained statements or views of the authors of each of the three books. The sample was selected by stratified random sampling and consisted of 182 executives and non-executives (73 males and 109 females) in the post office organisation in Malaysia. Findings: T-test results show that out of 23 statements made by Gray (1992), only 8 were supported, 10 were not supported, and 5 were actually true for the opposite gender. 6 out of 10 pairs of statements derived from Gray (2002) were supported, and 4 were not supported. Research, practical and social implications: Results from this sample suggest that men are more likely than women to agree with Gray (2002). Results also showed very weak support for Tannen's (1990) research. Interestingly, the results from this sample suggest that men have a greater tendency to gender-stereotype other men and women. Originality/Value: This is the first research in Malaysia, to test propositions relating to gender communication, from the three books. The two books by Gray are found in most big bookstores in Malaysia, and the third book is less easily available. However, results suggest that most of the principles in all the three books, which were written as a guide to gender communication, are in fact, not applicable to this sample in Malaysia.
\end{abstract}

Keywords: gender, communication, John Gray, Tannen, Mars and Venus

\section{Introduction}

The idea that women and men have different communication styles have become the theme of many best-selling books on gender differences, such as the two books written by Gray (1992, 2002) titled "Men are from Mars, Women are from Venus" and "Mars and Venus in the Workplace." Another book about the alleged differences in gender communication style is "You just don't understand: Women and Men in Conversation" by Tannen (1990). These books claim that there are significant and consistent differences in communication styles between men and women. The book by Tannen (1990) was written based on empirical research, whereas the books by Gray (1992, 2002) were written for the layperson. Both books by Gray are available in large bookstores in the US, UK and Asia. However, Gray (1992, 2002) did not state in either of his books, whether he conducted any empirical research. It is also interesting to note that Gray's (1992) book came out two years after the publication of Tannen's (1990) research. These books were written with the aim of improving communication between men and women in the workplace, in order that they can understand each other better and be able to reduce the communication gap in the work place, which will probably result in increased job satisfaction and productivity. These two authors claim that there are certain ways in which men and women differ. However, this is not true, as not everyone agrees with them (Wood and Dindia, 1998). This study aims to assess whether there are consistent gender differences in communication styles, as mentioned by the two authors.

Murphy (2001) argues that Gray's work provides a "disturbing interpretive framework" (p. 151) for understanding communication based on a "sexist form of anthropology" (p. 164). Furthermore, Gray (1992, 2002) himself did not claim to have conducted any scientific research, and his pronouncements are based purely 
on a theory that is not supported by empirical research (Wood and Dindia, 1998). In fact, Gray's statements are often contradicted by the findings of many respected scholars, mentioned in the literature review.

Consequently, the main objective of this research is to test the propositions that Gray $(1992,2002)$ and Tannen (1990) have stated in their books, in the context of Malaysia - a developing country where if such archaic gender stereotypes are true, then it will most likely be found here, as Malaysia is well-known for its high power-distance culture (Hofstede 1980). On the other hand, if such stereotypes are not found to be true in this country, then it is rather unlikely to exist anywhere else on this planet (and perhaps exist only in Gray's world). Hofstede (1980), in his book, also posed the question of whether American theories are applicable abroad. This justifies the research to be conducted in Malaysia. This research aims to verify, within the Malaysian context, whether the propositions stated in all the three books are accurate explanations for the differences in communication and working styles that are alleged to exist between genders. In other words, the main question posed in this study is: are the differences gender-related or do they exist irrespective of gender? This is the research question that this study aims to address. Differences in communication and working styles can lead to misunderstanding and frustrations between the sexes and may ultimately impact on decision-making in the work place. As more and more women are becoming entrepreneurs and entering the job market, it is therefore important to find out whether differences in gender contribute to this problem, or whether such problems occur independently of gender.

\section{Literature Review}

\subsection{Feminism}

Foss (2010) criticised Mirchandani (1999), Ahl (2006) and Lewis (2006) for conducting entrepreneurship research that measure women against the standards of men. Feminist empiricism and feminist standpoint theory have been criticised for being essentialist in character i.e., by claiming that certain traits are unique to men and certain traits are unique to women. Di Stephano (1990), Bordo (1990) and Haraway (1991), introduced the gender-as-process ("post-structuralist feminism") in which gender is no longer treated as two groups with distinct and coherent patterns of behavior. According to Petterson (2004), masculine and feminine traits vary over time and between places and discourses, as gender is a cultural code that needs to be negotiated and renegotiated.

On the other hand, Gray $(1992,2002)$ and Tannen (1990) assert that there are clear and somewhat fixed differences between ommunication and working styles of men and women. These differences were alleged to exist irrespective of whether the women were entrepreneurs or were employed as staff. Therefore, the topics pertaining to the alleged differences in communication and the working styles of men and women that were highlighted by Gray $(1992,2002)$ and Tannen $(1990)$, as well as other research that either support or contradict these propositions, need to be discussed, and they are discussed in the literature review.

\subsection{Problem Solving}

One of the biggest differences between men and women in the workplace, is how they approach problems. According to Gray (1992), there are differences in how women solve problems, as compared to men. When faced with a dilemma, men's first reaction is to go to his cave and solve it on his own, but women's first reaction is to reach out and include others by talking about it.

\subsection{Competitiveness}

Men's communication in teams tend to be more competitive, and are used to express dominance (Briton and Hall, 1995; LaFrance and Henley, 1994). In one study, interruption behavior increased among men in groups with higher proportions of males (Karakowsy, McBey and Miller, 2004). These results suggest that males may be more competitive with other males, when working in team settings. Men are competitive speakers who are more likely to engage in conflict by arguing and issuing commands, while women are cooperative and are more likely to avoid conflict by agreeing and making suggestions, rather than issuing commands (Tannen, 1990). Some studies have supported the long-standing assumption, based on cultural stereotypes, that women have a more cooperative orientation than men, and that men are more competitive than women (Rubin and Brown, 1975). When interacting, women are expected to communicate in ways that emphasise cooperation, collaboration and sensitivity to others' feelings, while men communicate in ways that exert control, establish status and maintain independence. Men define their sense-of-self through their actions, and their ability to achieve results at work. In the work place, men always do things to prove themselves, and develop their power and skills. Although more women are becoming entrepreneurs and are increasingly representative in various professions, stereotypes and 
traditional unfair social prejudices based on sex continue to have a negative impact on them, leading to inferiority complex and lower self-esteem (Rubin and Brown, 1975).

\subsection{Competency}

Some research have shown that men tend to value male input over female input, and assume that men are more competent than women (Martin, 1996; Pierce, 1995; Williams, 1995). Males are also more likely than females, to intentionally withhold information to further their own positions, or harm another's position (Deal, 2000). Such ways that men accomplish something have often resulted in them being seen as competent, but this is not the case when it comes to women. Conversation style differences often lead to women being evaluated as less competent than men.

Men, or also known as Martians by Gray (1992), value power, competency, efficiency, action, achievement, and accomplishment. His view on women's sense-of-self in the work place is defined primarily by the quality of her work relationships. In the work place, women respect efficiency and achievement, but value support, trust, and communication more. He also claimed that women are more interested in the quality of work relationships, personal expression, and mutual support, than Martians. They experience fulfillment by sharing, collaborating and cooperating, in the process of achieving greater success.

Gray's (1992) old-fashioned attitudes and support of traditional, power-based relationships are evident in his writing. He states that "men value power, competency, efficiency and achievement" (p.16). Women, on the other hand, are completely at the mercy of their hormones, and feel no connection between self-esteem and their own accomplishments. Gray (1992; p. 21) said “A woman's self-esteem generally rises and falls in a cycle not necessarily in sync with her menstrual cycle, but it does average out at twenty-eight days". Women who go out of their homes to work "put on the Martian suits" (1992) and leave behind daily tasks such as housework and childcare, which are their primary responsibility. Men are encouraged to help with domestic tasks on an occasional basis, strictly as a method of "keeping her love tank full and the score even" (p. 186).

\subsection{Asking Questions}

Asking questions mean different things to men and women. According to Tannen (1994), the language of conversation is primarily a language of rapport for women i.e., a way of establishing connections, negotiating relationships and rapport. On the other hand, men talk to preserve independence, and negotiate and maintain status in a hierarchical social order i.e., a language of report. It has also been found that men tend to interrupt more, and they are less likely to ask questions (Tannen, 1990; Coates, 1996; Lackoff and Johnson, 1990). Women are more likely than men to ask questions and agree with others, and women are less likely than men to challenge others' statements and frame others' arguments. These differences are theorised to reflect women's greater concerns for cooperation and connection in their relationships. These conclusions are consistent with Tannen's (1990) notion that men are more likely to interpret messages according to levels of dominance, whereas women are more likely to interpret them according to levels of supportiveness.

\subsection{Directness and Indirectness}

Tannen (1990) describes how, when questioned about why more women were not hired or promoted, male managers attributed it to the women's lack of confidence. One behavior that may be seen by others as a lack of confidence, is the indirect way women give orders. Men and women often differ in the ways they manage people and give orders. Several studies have shown that women tend to soften their demands and statements, whereas men tend to be more direct (Coates, 1989; Tannen, 1990; Spender, 1980; Case, 1994). Women often use tagged phrases like "don't you think" following the presentation of an idea, "if you don't mind" following a demand, or "this may be a silly idea, but" preceding a suggestion. It is important to note that tentative communication does not necessarily mean that the speaker actually feels tentative, or is lacking in confidence. Similarly, more direct communication does not necessarily mean that the person is arrogant, bossy or feels superior. Women have also been persuaded that it is not "businesslike" to complain (Perriton, 2009).

\subsection{Trouble Talk}

Tannen (1990) asserts that men are confused by the various ways in which women use conversation to be intimate with others. One of these ways is "trouble talk" i.e., talking about one's troubles or problems. She claims that for women, talking about troubles is the essence of connection. It signifies and creates closeness. Men, however, may interpret trouble talk as a request for advice, and they could respond by giving solutions. The female then, feels cut-off. Men tend to provide solutions, when women actually want to talk about their problems, in their quest to create relationships. 
Tannen (1990) went on to argue that, as a consequence of these general differences in communication styles, women and men may tend to choose different behavioral responses (such as giving sympathy, and giving advice respectively) when confronted with "trouble talk". These gender differences can lead to problems and misunderstandings in communication between women and men.

\subsection{Talk Time}

There have been stereotypes that women talk more than men (Coates, 1993). However, studies generally show that in a mixed-gender conversation, the average amount of time for which a man will talk will be approximately twice as long as the average amount for which a woman will talk (Spender, 1980). Women may perceive men's conversational dominance as an exercise of power. As a consequence, women who talk for more than one third of the available time, may be regarded by others as talking too much.

\subsection{Conversational Topics}

Linguistic variance between men and women take place in the topics they choose to discuss. Women tend to select topics of a more personal type such as their family, their emotions, and their friendships. Besides that, women are not afraid to embed details in their speech, in order to involve people in the events being described. Men, however, use more abstract communication, speaking in general terms (Kramarae and Treicher, 1983; Schaef, 1985).

Men tend to use linear speech, moving sequentially through points, unlike women. Women use a personal style, allowing them to divulge details of experience and personal disclosures. Linear speech requires less intimacy and also reaffirms the conversational goal as being one of information exchange. Women's conversations focus more on the development and maintenance of conversations, and the relationships between the speakers through supportive listening.

\subsection{Studies Done in Other Countries}

Studies done outside the U.S.A revealed further distinctions. For instance, in a study that investigated the communicative strategies used by Japanese males and females in mixed-gender formal interactions, quantitative results show that female and male hosts use polite strategies, but female guests are more assertive than male guests. However, the qualitative results show a much more complex picture; domineering and cooperative strategies were used by both, male and female participants (Tanaka, 2009). In another study conducted among science teachers from secondary schools in Taiwan, it was found that female science teachers perceived greater collegiality among teachers, higher gender equity among students, and stronger professional interest, and male science teachers perceived lower work pressure and better teacher-student relations (Huang \& Fraser, 2009). Also, in a study conducted in the three Netherlands schools, it was discovered that female students in the mixed-gender groups did not learn to solve physics problems as well as male partners, or as female students in all-female dyads. Analyses of interactive behaviours showed that female students in the mixed gender groups devoted less time actively seeking solutions and spent more time asking questions, than their male partners. Female students in the all-female dyads did not differ in interactive behaviours or post-test performance from males. Females in all-female dyads had a more balanced interactive style, than females in the mixed-gender dyads (Harskamp, Ding \& Suhre, 2008).

\subsection{General Propositions by Tannen (1990) and Gray $(1992,2002)$}

Tannen (1990) suggested that men and women follow different rules of communication behavior, and that a conversation between men and women is an interaction of opposite cultures. Tannen (1990, p. 77) stated that "For most women, the language of conversation is primarily a language of rapport which is a way of establishing connections and negotiating relationships. Emphasis is placed on displaying similarities and matching experiences. For most men, talk is primarily a means to preserve independence and negotiate and maintain status in a hierarchical social order."

Gray (1992) may have taken Tannen's (1990) propositions further by declaring that men and women not only communicate differently, but have so little in common as to be from completely different planets. Gray (2002) portrayed men and women as foreign entities struggling to comprehend one another in the workplace. Many gender scholars do not dispute that, some differences exist in men's and women's approach to relationships (Basow and Rubenfeld, 2003; Cole, 2004; Hekman, 1999; Wood, 1982, 2005). Since Gray's (1992) book was published, the phrase "Men are from Mars, Women are from Venus" has become a metaphor for expressing the existence and acceptance of innate gender differences and propagating stereotypes, despite a growing body of evidence that reveal that such differences are not significant. Gray's metaphor also does not leave room for the long validated results of the Bem's Sex Role Inventory (Wong McCreary and Duffy, 1990), which argued that 
men and women can and do develop attributes in both masculine and feminine gender domains. Gray's metaphor also fails to take into account the empirically supported premise that human communication styles are a social construction which encourages women more and men less, to develop traits that enhance interpersonal problem-based communication (Baird, 1976; Basow and Rubenfeld, 2003).

Gray $(1992,2002)$ failed to cite any empirical evidence (as it appears that he has not conducted any scientific research on the topic) to support his theories about specific communication characteristics, and his findings frequently conflict with reputable and scholarly research in these areas. For example, Kim and Bresnahan (1996) examined the determination of intention or motive behind verbal strategy choices, and found no significant differences between what men and women perceive as important in communication. Men and women, across four cultures, both found constraints such as interruptions and self-disclosure, to be important in communication behaviour.

When Gray (1992) writes that men constantly interrupt their partners and offer solutions while "Venusians never offer solutions while someone else is talking" (p. 22), he is oversimplifying things. While there are studies that found that men interrupt women more often than women interrupt men, often as a show of power (Berryman-Fink and Brunner, 1987), a meta-analysis of studies on interruptions by Dindia (1987) found that such studies failed to account for the fact that communication behaviour is often interdependent. So, those who interrupt, may result in their partner's subsequent interrupting behaviour.

In Gray's world, women continually engage in self-disclosure, sharing their "process of inner discovery" (Gray, 1992; p.19) with anyone who will listen, while men will often stop communicating all together and become silent. A Martian would never "burden" another man with his problems and would rather watch TV or work on his car, than discuss his problems with a woman. Gray (1992, p. 30) states, "Instead he becomes very quiet and goes to his private cave to think about his problem, mulling it over to find a solution. When he has found a solution, he feels much better and comes out of his cave."

While Parsons and Bales (1955) described women as expressive and men as instrumental, Gilligan (1982) asserted that women measure everything in terms of relationships, and men measure in terms of logic. While Tannen (1990) declared that scholars and individuals must acknowledge that men and women communicate differently, many others see these distinctions as limiting.

\subsection{Studies That Contradict Tannen (1990) and Gray (1992, 2002)}

Dindia (1987) discovered that although both sexes interrupt, men do not interrupt more than women, especially in mixed-sex dyads, and that women's interruptions are no less assertive than men's interruptions. In fact, Dindia (2006) coined the metaphor, "Men are from North Dakota, women are from South Dakota" in an effort to emphasise that any existent differences between male and female communication practices are not planetary. Dindia and Allen's (1992) meta-analysis on sex differences in self-disclosure concurred with previous findings that women disclose more than men, but revealed that this is only true in same-sex dyads. When talking with men, women do not disclose any more than their male partners disclose.

Individuals who argue that there are inherently male and inherently female characteristics and behaviors, may be guilty of gender stereotyping (Eisenberg, Martin, and Fabes, 1996). This assumption that certain distinct characteristics are the essence of women while other, different and equally distinct characteristics are the essence of men, is known as essentialising (Wood, 1993). Generalised statements that specific characteristics or behaviors are true for all men, while others are true for all women, are based on the idea that behaviour is inherent and constant. Wood (2001) objects to efforts to essentialise women and men, in particular the assertion that communication practices are innate and unchangeable. Essentialising and gender stereotyping leave no room for individuality.

Wood and Dindia (1998) object to the solutions that Gray (1992) prescribes because they are a disservice to women and men who follow them, as they are not based on a theory that is supported by empirical research. Dindia and Allen (1992) conclude that, "it is time to stop perpetuating the myth that there are large differences in men's and women's self-disclosure" (p. 118). As such, there is a real need and a genuine justification for this research to be conducted in order to test the numerous propositions made by Gray $(1992,2002)$ and Tannen (1990). By doing so, it is hoped that communication and working styles of men and women in organisations can be better understood, coordinated and enhanced, and any gap between men and women can be reduced for a better understanding between the two genders in the work place. 


\section{Research Methodology}

\subsection{Sample}

The sample comprised of employees from the headquarters of the Malaysian Postal Services Company, also known as Pos Malaysia Berhad, located in Kuala Lumpur, Malaysia. There were several reasons for selecting only a single institution for this study. For a start, there were severe constraints on time and money, and it was not possible to explore both government and private sector institutions. Pos Malaysia Berhad is one of the few government institutions that have recently been privatised. As a result, it could arguably be treated as a hybrid of government and private sector institutions. It is also the largest, thus providing a substantial pool of potential respondents. Furthermore, the second researcher is an employee of Pos Malaysia and therefore, has access to the employees as respondents. Lastly, this institution was chosen because like Malaysia, the majority of the people here, are of the Malay race.

Negotiations were held with the Human Resource manager on the selection procedure of the participants. It was finally agreed that questionnaires could be sent to 300 employees i.e., 150 executives and 150 non-executives. Also, an equal number of questionnaires were sent to males and females at the executive and non-executive levels. Questionnaires were sent to all the 150 executives whose names were provided by the Human Resource manager. The 150 non-executive employees were selected using stratified random sampling to ensure respondents from each of the different levels were chosen, and questionnaires were distributed to them. However, out of the total of 300 questionnaires distributed, only 182 were completed and returned i.e., a response rate of $60.7 \%$.

\subsection{Measures}

The data collection was done through self-administered questionnaires consisting of four parts. Part A comprises of 23 statements related to communication styles adapted from the book "Men are from Mars, Women are from Venus" (Gray, 1992). Examples are "I appreciate reassurance at stressful times" and "I am very concerned with achieving the bottom line." The main purpose of these questions is to detect whether there are any significant differences between males and female respondents when describing themselves.

Part B comprises of 10 pairs of statements related to communication styles adapted from the book "Mars and Venus at the Workplace" (Gray, 2002). Each pair contained identical statements, but each related to a specific gender. Examples are "Men often ask directly for what they want" and "Women often ask directly for what they want." The stereotypes about males are also stated about females and vice versa as the first purpose is to test whether there is indeed such a general stereotype. The second purpose is to detect whether males or females, are more likely to engage in the process of stereotyping, whether of the same or of the opposite gender.

Part C comprises of 18 statements related to the findings by Tannen (1990). Examples are "Men emphasise status, power and independence" and "Women emphasise on connections, closeness and intimacy." The purpose is to test whether Tannen's (1990) findings could be replicated in Malaysia.

Part D comprises of questions related to demographics such as gender, age group, marital status, education, ethnicity and job level.

The statements in Parts A, B and C were translated to the Bahasa Malaysia language as the non-executive respondents in the organisation were well-versed in the local language and not English. The questionnaire was translated using the double translation method used by Chan (1991) as follows: The statements were first translated into the Bahasa Malaysia language. A second independent translator takes the translated version of the questionnaire and independently translates the instrument back to the English language. Any inconsistencies of meaning, mistranslations, lost words or phrases between the two English versions of the questionnaire and the translated Bahasa Malaysia version were then detected and the questionnaire was revised. A pilot test was then done with a sample size of 10 to reveal any undiscovered ambiguities.

\section{Results}

Table 1. Descriptive statistic

\begin{tabular}{lll}
\hline & & $\mathbf{\%}$ \\
\hline Gender & Male & 40.1 \\
Age group & Female & 59.9 \\
& $20-29$ years & 54.9 \\
& $30-39$ years & 25.8 \\
& $40-49$ years & 13.7 \\
& $>50$ & 5.5
\end{tabular}


Marital Status

Education

Ethnicity

Job Level
Single

Married

Secondary School

Diploma

11.5

Bachelor Degree

42.3

Postgraduate

3.9

Malay

94.0

Indian

4.4

Chinese

1.1

Others

0.5

Executive

46.2

Non-Executive

Descriptive analyses of the sample are shown in Table 1. More females completed and returned the questionnaires compared with men - female respondents made up $59.9 \%$ of the overall responses and male respondents made up $40.1 \%$. Regarding ethnicity, the Malay race formed the largest group by taking up $94.0 \%$ of the sample while the Indians made up $4.4 \%$, followed by the Chinese at $1.1 \%$. The remaining $0.5 \%$ was made up by $1 \mathrm{Sikh}$ employee referred as the 'Other' ethnic group.

$54.9 \%$ of the respondents were between 20 to 29 years old, while $25.8 \%$ were between 30 to 39 years old. $13.7 \%$ were from the age group of 40 to 49 years old. Respondents aged more than 50 years old made up the smallest representation at only $5.5 \%$. As for marital status, $57.1 \%$, of the respondents were married and $42.9 \%$ were either single or not married. $42.3 \%$ of the respondents had only secondary school education. $42.3 \%$ of the respondents had Bachelor degrees, $11.5 \%$ had Diplomas and 3.8\% had Postgraduate Degrees. $46.2 \%$ of the respondents were executives while $53.8 \%$ were non-executives.

\subsection{Part A}

Table 2. Independent Samples t-tests from part A (i.e. statements regarding the respondents themselves) where significant differences between male and female were found thus supporting Gray's (1992) propositions

\begin{tabular}{|c|c|c|c|c|c|c|}
\hline Code & Statements & Mean & Male & Female & Sig & Validation \\
\hline A1 & I like to do things by myself. & 5.24 & 6.06 & 4.39 & 0.00 & Supports Gray \\
\hline $\mathbf{A 2}$ & $\begin{array}{l}\text { I always evaluate the competence } \\
\text { of others when interacting. }\end{array}$ & 5.59 & 6.18 & 5.09 & 0.00 & Supports Gray \\
\hline A12 & $\begin{array}{l}\text { I get annoyed with people who let } \\
\text { their emotions interfere with their } \\
\text { competence. }\end{array}$ & 6.36 & 6.84 & 5.78 & 0.02 & Supports Gray \\
\hline A18 & $\begin{array}{l}\text { I am very concern with achieving } \\
\text { the bottom line. }\end{array}$ & 6.29 & 7.02 & 5.60 & 0.00 & Supports Gray \\
\hline A20 & $\begin{array}{l}\text { When I am talking to co-worker } \\
\text { of the opposite gender, I feel that I } \\
\text { am talking to a brick wall. }\end{array}$ & 4.14 & 3.37 & 4.87 & 0.00 & Supports Gray \\
\hline A21 & $\begin{array}{l}\text { I have trouble communicating } \\
\text { with co-worker of the opposite } \\
\text { gender. }\end{array}$ & 4.16 & 3.58 & 4.78 & 0.00 & Supports Gray \\
\hline A22 & $\begin{array}{l}\text { I often have trouble interpreting } \\
\text { messages from co-worker of the } \\
\text { opposite gender. }\end{array}$ & 4.26 & 3.73 & 4.89 & 0.00 & Supports Gray \\
\hline A23 & $\begin{array}{l}\text { I feel hurt and rejected when } \\
\text { co-worker of the opposite gender } \\
\text { grumble upon my request about } \\
\text { something. }\end{array}$ & 4.73 & 4.24 & 5.31 & 0.00 & Supports Gray \\
\hline
\end{tabular}

Only 8 out of the 23 statements made by Gray (1992) were supported (see Table 2). Men, prefer to do things by themselves, tend to evaluate the competence of others when interacting, get annoyed with people who let their 
emotions interfere with their competence, and are very concerned with achieving the bottom line. Women feel as if they are talking to a brick wall when talking to men, admit to having trouble communicating and interpreting messages from the opposite gender, and feel hurt and rejected when a co-worker of the opposite gender grumbles in response to their request about something.

Table 3. T-tests from part A (i.e. statements regarding the respondents themselves) where NO significant differences between male and female were found thus NOT supporting Gray's (1992) propositions

\begin{tabular}{|c|c|c|c|c|c|}
\hline Code & Statements & Mean & Male & Female & Sig \\
\hline $\mathbf{A 3}$ & $\begin{array}{l}\text { I dislike being questioned just for the sake of } \\
\text { connecting. }\end{array}$ & 5.36 & 5.52 & 5.06 & 0.13 \\
\hline A5 & I prefer independent activity rather than teamwork. & 4.62 & 4.05 & 4.85 & 0.18 \\
\hline A6 & $\begin{array}{l}\text { I am not concerned if someone at work doesn't like me, } \\
\text { as long as I have their respect. }\end{array}$ & 5.48 & 5.42 & 5.53 & 0.96 \\
\hline A7 & $\begin{array}{l}\text { I prefer to talk about work related matters rather than } \\
\text { personal matters. }\end{array}$ & 6.08 & 5.52 & 5.72 & 0.08 \\
\hline A8 & $\begin{array}{l}\text { If I'm confused I try to work it out myself rather than } \\
\text { ask for help or advice. }\end{array}$ & 4.96 & 4.82 & 5.15 & 0.23 \\
\hline A13 & $\begin{array}{l}\text { I find that talking about problems in the work place is } \\
\text { not worth the time it takes. }\end{array}$ & 5.75 & 5.83 & 5.85 & 0.43 \\
\hline A14 & $\begin{array}{l}\text { I'll go along with something I disagree with, rather than } \\
\text { make a stand. }\end{array}$ & 4.35 & 4.35 & 4.42 & 0.23 \\
\hline A15 & $\begin{array}{l}\text { I rely on gut feelings, more than logic, when making } \\
\text { difficult decisions. }\end{array}$ & 4.64 & 4.39 & 4.87 & 0.53 \\
\hline A16 & $\begin{array}{l}\text { I keep my negative thoughts and feelings to myself } \\
\text { rather than share them. }\end{array}$ & 5.22 & 5.47 & 5.05 & 0.29 \\
\hline A19 & I often ask clarifying questions to feel supported. & 6.00 & 6.31 & 5.74 & 0.05 \\
\hline
\end{tabular}

An amazing 10 out of 23 statements made in Gray (1992) about men and women were not supported (see Table 3). This begs the question of the utility of using Gray's (1992) book as a guide to understanding the alleged differences in communication between the two genders.

Table 4. T-tests from part A (i.e. statements regarding the respondents themselves) where significant differences between male and female were found BUT IN THE DIRECTION OPPOSITE of Gray's (1992) propositions

\begin{tabular}{|c|c|c|c|c|c|}
\hline Code & Statements & Mean & Male & Female & Sig \\
\hline A4 & $\begin{array}{l}\text { If I have personal problems I have to watch } \\
\text { myself carefully so that they don't interfere } \\
\text { with my work. }\end{array}$ & 6.46 & 6.94 & 5.73 & 0.00 \\
\hline A9 & $\begin{array}{l}\text { Unresolved conflict makes me very } \\
\text { uncomfortable. }\end{array}$ & 6.65 & 6.90 & 6.06 & 0.00 \\
\hline A10 & $\begin{array}{l}\text { If someone appears to be upset I'll find an } \\
\text { opportunity to let them talk about it with me. }\end{array}$ & 6.20 & 6.48 & 5.81 & 0.01 \\
\hline A11 & $\begin{array}{l}\text { If I am unsure of something at work, I will } \\
\text { seek for advice or assistance. }\end{array}$ & 6.96 & 7.81 & 6.06 & 0.00 \\
\hline A17 & I appreciate reassurance at stressful times. & 5.91 & 6.39 & 5.44 & 0.00 \\
\hline
\end{tabular}

Table 4 shows what is probably one of the most startling findings in this study - 5 out of 23 of the statements made in Gray (1992) were not only unsupported, but were actually more true for the opposite gender. Men and not women surprisingly admitted that if they had personal problems, they had to watch themselves carefully so that they do not interfere with their work, unresolved conflict makes them feel very uncomfortable, and if someone appears to be upset, they will find an opportunity to talk about it with them. Men also feel that if they are unsure of something at work, they will seek advice or assistance and they appreciate reassurance at stressful times. So it appears that Malaysian men have more of such fragile, emotional characteristics and sensitive feelings, compared with Malaysian women. This begs the question of the value of using Gray's (1992) book as a 
guide to understanding gender-based communication in Malaysia - it is not only misleading, but rather dangerous.

Thus, a total of 15 out of 23 of the statements pertaining to gender communication made in Gray (1992) were not supported. Based on the results, it would therefore not seem appropriate to recommend Malaysians, especially the Malays (both men and women) of reading and using the book as a guide to gender-related communication.

\subsection{Part $B$}

Table 5. Paired samples t-test for part B

\begin{tabular}{|c|c|c|c|c|c|c|}
\hline & & \multicolumn{3}{|c|}{ All cases } & \multirow{2}{*}{$\begin{array}{l}\text { Men } \\
\text { only } \\
\text { Results }\end{array}$} & \multirow{2}{*}{$\begin{array}{c}\begin{array}{c}\text { Women } \\
\text { only }\end{array} \\
\text { Results }\end{array}$} \\
\hline & & Mean & $\begin{array}{c}\text { Std } \\
\text { Deviation }\end{array}$ & Sig Results & & \\
\hline \multirow{2}{*}{ Pair 1} & B1: Men often ask directly for what they want & 5.86 & 2.128 & \multirow{2}{*}{$.015 \mathrm{M}>\mathrm{W}$} & \multirow{2}{*}{$\mathrm{M}>\mathrm{W}$} & \multirow{2}{*}{-} \\
\hline & B2: Women often ask directly for what they want & 5.36 & 1.851 & & & \\
\hline \multirow{2}{*}{ Pair 2} & $\begin{array}{l}\text { B3: Men talk less about the problem and more about } \\
\text { the solution }\end{array}$ & 5.90 & 1.875 & \multirow{3}{*}{$.015 \mathrm{M}>\mathrm{W}$} & \multirow{3}{*}{$\mathrm{M}>\mathrm{W}$} & \multirow{3}{*}{-} \\
\hline & $\begin{array}{l}\text { B4: Women talk less about the problem and more } \\
\text { about the solution }\end{array}$ & 5.46 & 1.624 & & & \\
\hline \multirow{2}{*}{ Pair 3} & $\begin{array}{l}\text { B5: Men speak more confident than women in the } \\
\text { work place }\end{array}$ & 6.08 & 1.889 & & & \\
\hline & $\begin{array}{l}\text { B6: Women speak more confident than women in the } \\
\text { work place }\end{array}$ & 5.79 & 1.787 & .085 & $\mathrm{M}>\mathrm{W}$ & $\mathrm{M}<\mathrm{W}$ \\
\hline \multirow{2}{*}{ Pair 4} & $\begin{array}{l}\text { B7: Men feel that solving a problem is an opportunity } \\
\text { to demonstrate sharing, cooperation, and } \\
\text { collaboration }\end{array}$ & 5.79 & 2.103 & \multirow{3}{*}{.461} & \multirow{3}{*}{$\mathrm{M}>\mathrm{W}$} & \multirow{3}{*}{$\mathrm{M}<\mathrm{W}$} \\
\hline & $\begin{array}{l}\text { B8: Women feel that solving a problem is an } \\
\text { opportunity to demonstrate sharing, cooperation, and } \\
\text { collaboration }\end{array}$ & 5.68 & 1.701 & & & \\
\hline \multirow{2}{*}{ Pair 5} & $\begin{array}{l}\text { B9: Men will take it personally when I forget to do } \\
\text { little things }\end{array}$ & 4.86 & 1.868 & & & \\
\hline & $\begin{array}{l}\text { B10: Women will take it personally when I forget to } \\
\text { do little things }\end{array}$ & 5.47 & 1.826 & $.002 \mathrm{M}<\mathrm{W}$ & $\mathrm{M}<\mathrm{W}$ & $\mathrm{M}<\mathrm{W}$ \\
\hline \multirow{2}{*}{ Pair 6} & B11: Men earn trust and support by listening more & 5.90 & 1.887 & \multirow{2}{*}{.633} & \multirow{2}{*}{-} & \multirow{2}{*}{-} \\
\hline & B12: Women earn trust and support by listening more & 5.81 & 1.739 & & & \\
\hline \multirow{2}{*}{ Pair 7} & B13: Men want to work cooperatively on project & 6.30 & 1.842 & \multirow{2}{*}{$.032 \mathrm{M}>\mathrm{W}$} & \multirow{2}{*}{$\mathrm{M}>\mathrm{W}$} & \multirow{2}{*}{-} \\
\hline & B14: Women want to work cooperatively on project & 5.99 & 1.732 & & & \\
\hline \multirow{2}{*}{ Pair 8} & B15: Men are always being competitive with me & 6.00 & 1.787 & \multirow{2}{*}{$.018 \mathrm{M}>\mathrm{W}$} & \multirow{2}{*}{$\mathrm{M}>\mathrm{W}$} & \multirow{2}{*}{ - } \\
\hline & B16: Women are always being competitive with me & 5.70 & 1.794 & & & \\
\hline \multirow{2}{*}{ Pair 9} & $\begin{array}{l}\text { B17: Men accept complements for their achievement } \\
\text { in a positive way }\end{array}$ & 6.45 & 1.785 & & & \\
\hline & $\begin{array}{l}\text { B18: Women accept complements for their } \\
\text { achievement in a positive way }\end{array}$ & 6.30 & 1.734 & .257 & - & - \\
\hline Pair & $\begin{array}{l}\text { B19: Men complain about problems because they } \\
\text { want their problems to be acknowledged }\end{array}$ & 5.65 & 1.874 & & & \\
\hline 10 & $\begin{array}{l}\text { B20: Women complain about problems because they } \\
\text { want their problems to be acknowledged }\end{array}$ & 6.12 & 1.950 & $.010 \mathrm{M}<\mathrm{W}$ & - & $\mathrm{M}<\mathrm{W}$ \\
\hline
\end{tabular}


Part B comprises of 10 pairs of statements related to communication styles adapted from the book "Mars and Venus at the Workplace" (Gray, 2002). Each pair contained identical statements but each related to a specific gender. The stereotypes about males are also stated about females and vice versa, as the main purpose is to test whether there is indeed such a prevailing stereotype. Independent samples T-Test were conducted for each pair of statements, for the entire sample (see Table 5, under the heading of "All cases"). When both male and female respondents were taken into account, it was found that men are more likely than women to: ask directly for what they want; talk less about the problem and more about the solution; and want to work cooperatively on a project. Also, women are more likely than men to take it personally when they forget to do little things and; complain about problems because they want their problems to be acknowledged.

However, when only male respondents were selected for analyses, the results had similarities and differences. The similarities will be explained first. Male respondents do agree that men generally: often ask directly for what they want; talk less about the problem and more about the solution; want to work cooperatively on a project; are cooperative and; are competitive. As with "all cases" male respondents do perceive that women are more likely to take it personally when they forget to do little things.

Regarding the differences, only the male respondents tend to believe that generally, men are more confident than women at the workplace, and that men feel that solving a problem is an opportunity to demonstrate sharing, cooperation and collaboration. This is indeed interesting because this view is not shared at all by the female respondents - in fact their view is the contrary. Female respondents are of the view that women are more confident than men at the workplace; and women feel that solving a problem is an opportunity to demonstrate sharing, cooperation and collaboration. Perhaps this is the area of greatest misunderstanding between the two genders.

Having said that, there is some common ground - both men and women agree that women rather than men will take it personally when they forget little things; and women complain about problems because they want their problems to be acknowledged.

\subsection{Part $C$}

The main purpose of Part C of the questionnaire was to test whether Tannen's (1990) findings could be replicated in Malaysia - and the results showed very weak support overall. When both male and female respondents were taken into account (i.e., "all cases"), none of the mean scores were above 6.5. Only 9 out of 18 statements had mean scores of above 6.0 - the highest was 6.45 for the statement "Men generally know what they are going to say before they speak." Thus, the findings of Tannen (1990) could not have been said to have been successfully replicated in this study. What is interesting to note however, is that when the mean scores of the male respondents were compared with the female respondents in an independent sample T-Test, scores of the male respondents were significantly higher than the female respondents in 15 out of 18 instances. One interpretation of these findings could be that men are more likely than women, to hold stereotypes about other men and women. Among the most salient are the following statements: Men emphasise status, power and independence; women emphasise on connections, closeness and intimacy; men complain that women talk on and on; men generally know what they are going to say before they speak; by using "may I" or "let me" a man makes it easier for a women to accept his support; women often feel relief just by telling someone what they have to do; and as a manager, limit giving directions to the absolute minimum when dealing with men as the more independence a man gets the more he will appreciate.

Table 6. Independent Samples T-test for Part C (Tannen 1990)

\begin{tabular}{llllll}
\hline Code & Statements & Mean & $\begin{array}{l}\text { Men } \\
\text { only }\end{array}$ & $\begin{array}{l}\text { Women } \\
\text { only }\end{array}$ & Sig \\
\hline C1 & Men emphasize status, power and independence. & 6.27 & $\mathbf{6 . 8 5}$ & 5.89 & 0.00 \\
C2 & $\begin{array}{l}\text { Women emphasize on connections, closeness and } \\
\text { intimacy. }\end{array}$ & 6.19 & $\mathbf{6 . 5 9}$ & 5.93 & 0.04 \\
& Men complain that women talk on and on. & 6.29 & $\mathbf{6 . 8 1}$ & 5.94 & 0.01 \\
C4 & Women complain that men do not listen. & 6.18 & 6.40 & 6.03 & $\begin{array}{l}\text { Not } \\
\text { sig } \\
\text { C5 }\end{array}$ \\
& Men talk to boast about their accomplishment. & 5.97 & 5.82 & 6.06 & $\begin{array}{l}\text { Not } \\
\text { sig }\end{array}$
\end{tabular}


C6 Women downplay their accomplishments to avoid being braggarts and to take the other people's feelings into account.

C7 Men generally know what they are going to say before they speak

6.20

6.45

6.40

6.06

Not

C8 Women just begin talking and gradually discover what she wants to say. Men interrupt women with solutions.

C9

Women make unsolicited suggestions regarding how they could do things better

C11 Men thinks that women have nothing much to say when she talks less.

$\begin{array}{lll}6.11 & 5.50 \quad 0.04\end{array}$

C12 Women think that they are being polite by talking less.

6.01

$$
\text { Not }
$$

$$
5.56
$$

$$
\text { sig }
$$

Not

C13 When men say, "Would you like my help?" or "Can I help?" women will often say no when they really mean yes.

$\mathbf{C 1 4}$ By using "May I" or Let me" a man makes it easier for a woman to accept his support.

$\begin{array}{lll}6.73 & 5.88 & 0.01\end{array}$

$\mathbf{C 1 5}$ To a man, "Could you" sounds like a question and not a request.

C16 Women often feel relief just telling someone what they have to do.

Not

$\begin{array}{llll}6.31 & \mathbf{6 . 6 4} & 6.09 & 0.05\end{array}$

C17 As a manager, limit giving directions to the absolute minimum when dealing with men. The more independence a man gets, the more he will appreciate.

$\begin{array}{llll}6.21 & \mathbf{6 . 8 8} & 5.76 & 0.00\end{array}$

C18 When a woman's anger is personal, resulting from her feeling personally attacked, she is often viewed as blaming others and taking no responsibility.

$\begin{array}{llll}5.72 & 6.05 & 5.50 & \begin{array}{l}\text { Not } \\ \text { sig }\end{array}\end{array}$

\section{Conclusion}

The main objective of this research is to investigate whether there are differences in communication and behaviour of men and women, in ways that are propagated by Gray (1992, 2002) and Tannen (1990). Overall, the results obtained from this sample were not supportive of the propositions by Gray (1992, 2002) and Tannen (1990). In Part A of the questionnaire, out of the 23 statements made by Gray (1992), only 8 were supported, 10 were not supported and 5 were actually in the opposite direction (i.e., the statements made by Gray about men were actually more true about women and vice versa). This indeed casts great doubt about the often touted usefulness of reading Gray's (1992) book, as far as this sample is concerned.

Part B of the questionnaire had slightly better outcomes as 6 out of 10 pairs of statements made by Gray (2002) were supported and 4 were not supported. When only male respondents were selected for analyses, paired sample T-Test showed that 7 out of the 10 pairs of statements were supported. However, when only female respondents were selected only 4 out of the 10 pairs of statements were supported. This suggests that men are more likely than women to agree with Gray (2002) - something that we should not be too surprised about.

In Part C, the results showed very weak support overall for Tannen's (1990) research. The questionnaire had a mid-point of 5 and none of the mean scores of the respondents were above 6.5. Some might say that the lack of strong support for Tannen's (1990) findings is surprising as it was an empirical research. However, it is rather dated (i.e., 20 years ago) and there have been a lot of changes in the world since then. However, the greatest contribution to knowledge from the results of Part $\mathrm{C}$ of the questionnaire was that, men have a greater tendency to gender-stereotype others, whether they are men or women. This is indicated by the higher mean scores of male respondents compared with female, in this sample. 
In conclusion, this research is indeed timely in that it addresses the long disservice to women. We need to stop perpetuating the myth that there are large differences in communication styles between men and women. In particular, it is critical to understand that even if there are usual tendencies in the ways in which men and women communicate, these generalisations certainly do not apply to all men and all women. There are certainly some men who fit the communication characteristics described here as common to women, and there are certainly some women who fit the characteristics described here as common to men. It may be more useful to appreciate that different people may have different ways of communicating, than to assume that all women communicate one way and all men communicate in another way. There are different styles of communication and most of these differences are independent of gender. So the way forward into the future, would be to train people on how to communicate better, by making them aware that different people have different preferences and styles of communication. The emphasis should be to match the appropriate communication style with the individual preference and needs of the audience or listener, rather than essentialising and gender-stereotyping.

As with all research, this one is also without limitations. Small sample size, one organisation, limited geographic location and the fact that most of the respondents are of the Malay race are the obvious limitations. However, despite these limitations, this research in indeed timely as the debate about the alleged existence of gender differences has gone on long enough. Furthermore, it is not the intent of this research to generalise beyond the sample. Rather, its intent is to show that what has been propagated by Gray $(1992,2002)$ and Tannen (1990), is certainly not true for this sample of post office workers in Malaysia. It is hoped that this research will be the catalyst for many further replication studies all over the world, so that a bigger and clearer picture can be seen.

\section{References}

Ahl, H. (2002). The construction of the female entrepreneur as the other. In Czarniawska, B., \& Höpfl, H. (Eds.), Casting the Other: The Production and Maintenance of Inequalities in Work Organizations (pp. 52-67). London: Routledge.

Baird, J. E., Jr. (1976). Sex differences in group communication: A review of relevant research. Quarterly Journal of Speech, 62, 179-192. http://dx.doi.org/10.1080/00335637609383331

Basow, S. A., \& Rubenfeld, K. (2003). "Troubles talk": Effects of gender and gender typing. Sex Roles, 48(3-4), 183-187. http://dx.doi.org/10.1023/A:1022411623948

Berryman-Fink, C., \& Brunner, C. C. (1987). The effects of sex of source and target on interpersonal conflict management styles. Southern Speech Communication Journal, 53, 38-48. http://dx.doi.org/10.1080/10417948709372711

Bordo, S. (1990). Feminism, postmodernism and gender-scepticism. In Nicholson, L. (Ed.), Feminism/Postmodernism (pp. 63-82). London: Routledge.

Briton, N. J., \& Hall, J. A. (1995). Beliefs about female and male nonverbal communication. Sex Roles, 32, 79-90. http://dx.doi.org/10.1007/BF01544758

Case, S. (1994). Gender differences in communications and behaviour in organisations. In Davidson, M. J., \& Burke, R. J. (Eds.), Women in Management: Current Research Issues (pp. 144-63). London: Paul Chapman Publishing.

Chan, D. W. (1991). The Beck Depression Inventory: What difference does the Chinese version make? A Journal of Consulting and Clinical Psychology, 3(4), 616-622. http://dx.doi.org/10.1007/BF01544758

Coates, J. (1989). Women's speech, women's strength? York Papers in Linguistics, 13, 65-76.

Coates, J. (1996). Women Talk: Conversation Between Women Friends. Blackwell, Oxford.

Cole, N. D. (2004). Gender differences in perceived disciplinary fairness. Gender, Work and Organization, 11(3), 254-279. http://dx.doi.org/10.1111/j.1468-0432.2004.00231.x

Deal, J. J. (2000). Gender differences in the intentional use of information in competitive negotiations. Small Group Research, 31, 702-23. http://dx.doi.org/10.1177/104649640003100604

Di Stefano, C. (1990). Dillemmas of difference: feminism, modernity and postmodernity. In Nicholson, L. (Ed.), Feminism/Postmodernism (pp. 63-82). London: Routledge.

Dindia, K. (1987). The effects of sex of subject and sex of partner on interruptions. Human Communication Research, 13, 345-371. http://dx.doi.org/10.1111/j.1468-2958.1987.tb00109.x 
Dindia, K. (2006). Men are from North Dakota, women are from South Dakota. In K. Dindia, \& D. J. Canary (Eds.), Sex differences and similarities in communication (2nd ed. pp. 3- 20). Mahwah, NJ: Lawrence Erlbaum Associates.

Dindia, K., \& Allen, M. (1992). Sex differences in self-disclosure: A meta-analysis. Psychological Bulletin, 112 , 106-124. http://dx.doi.org/10.1037//0033-2909.112.1.106

Eisenberg, N., Martin, C., \& Fabes, R. (1996). Gender development and gender effects. In D. Berliner, \& R. Calfee (Eds.), Handbook of educational psychology (pp. 358-396). New York: Prentice-Hall.

Foss, L. (2010). Research on entrepreneur networks: The case for a constructionist feminist theory perspective. International Journal of Gender and Entrepreneurship, 2(1), 83-102. http://dx.doi.org/10.1108/17566261011026565

Gilligan, C. (1982). In a different voice. Cambridge, MA: Harvard University Press.

Gray, J. (1992). Men are from Mars and women are from Venus: A practical guide for improving communication and getting what you want in your relationship. New York: Harper Collins.

Gray, J. (2002). Mars and Venus at the Work place: A practical guide for improving communication and getting what you want in your relationship. New York: Harper Collins.

Haraway, D. J. (1991). Simians, Cyborgs, and Women. The Reinvention of Nature. London: Free Association Books.

Harskamp, E., Ding, N., \& Suhre, C. (2008). Group composition and its effect on female and male problem-solving in science education. Educational Research, 50(4), 307-318. http://dx.doi.org/10.1080/00131880802499688

Hekman, S. J. (1999). The future of differences: Truth and method in feminist theory. Cambridge, UK: Polity Press.

Hofstede, G. (1980). Motivation, Leadership, and Organizations: Do American Theories Apply Abroad? Organizational Dynamics, 42-63. http://dx.doi.org/10.1016/0090-2616(80)90013-3

Huang, S. Y. L., \& Fraser, B. J. (2009). Science Teachers' Perceptions of the School Environment: Gender Differences. Journal of Research in Science Teaching, 46(4), 404-420. http://dx.doi.org/10.1002/tea.20284

Karakowsy, L., McBey, K., \& Miller, D. (2004). Gender perceived competence and power displays: Examining verbal interruptions in a group context. Small Group Research, 35, 407-439. http://dx.doi.org/10.1177/1046496404263728

Kendall, S., \& Tannen, D. (1997). Gender and language in the workplace. In Kotthoff, H., \& Wodak, R. (Eds.), Communicating Gender in Context. Amsterdam: Benjamins.

Kim, M-S., \& Bresnahan, M. (1996). Cognitive basis of gender communication: A cross-cultural investigation of perceived constraints in requesting. Communication Quarterly, 44(1), 53-69. http://dx.doi.org/10.1080/01463379609370000

Kramarae, C., \& Treichler, P. A. (1983). Gender, language and the workplace: an exploratory study. Women in Management Review, 22(4), 319-336.

LaFrance, M., \& Henley, N. M. (1994). On oppressing hypotheses: Or differences in nonverbal sensitivity revisited. In H. L. Radtke, \& H. J. Stam (Eds.), Power/gender: Social relations in theory and practice (pp. 287-311). London: Sage, Ltd.

Lakoff, G., \& Johnson, M. (1990). Metaphors we live by. Chicago: University of Chicago Press.

Lewis, P. (2006). The quest for invisibility: female entrepreneurs and the masculine norm of entrepreneurship. Gender, Work and Organization, 13(5), 453-69. http://dx.doi.org/10.1111/j.1468-0432.2006.00317.x

Martin, P. Y. (1996). Men, masculinities and management: Gendering and evaluating dynamics. In D. L. Collinson, \& J. Hearn (Eds.), Men as managers, managers as men: Critical perspectives on masculinity (pp. 186-209). London: Sage Ltd.

Mirchandani, K. (1999). Feminist insight on gendered work: new directions in research on women and entrepreneurship. Gender, Work and Organization, 6(4), 224-235. http://dx.doi.org/10.1111/j.1468-0432.2006.00317.x 
Murphy, K. (2001). What does John Gray have to say to feminism? Continuum: Journal of media \& cultural studies, 15(2), 159-167.

Parsons, T., \& Bales, R. F. (1955). Family, socialization, and interaction process. Glencoe, I: Free Press.

Perriton, L. (2009). "We Don't Want Complaining Women!" A Critical Analysis of the Business Case for Diversity. Management Communication Quarterly, 23(2), 218-243. http://dx.doi.org/10.1177/0893318909343122

Petterson, K. (2004). Masculine entrepreneurship - the Gnosjö discourse in a feminist perspective. In Hjorth, D., \& Steyaert, C. (Eds.), Narrative and Discursive Approaches in Entrepreneurship. A Second Movement in Entrepreneurship Book (pp. 177-93). Aldershot: Edward Elgar.

Pierce, J. L. (1995). Gender trials: Emotional lives in contemporary law firms. Berkeley, CA: University of California Press.

Rubin \& Brown (1975). Managers' conflict management style and leadership effectiveness: The moderating effects of gender. Sex Roles, 29(5-6), 405-420.

Schaef, A. (1985). Women's Reality: An Emerging Female System in a White Male Society. San Francisco, CA: Harper \& Row.

Spender, D. (1980). Man Made Language. London: Routledge and Kegan Paul Ltd.

Tanaka, L. (2009). Communicative stances in Japanese interviews: Gender differences in formal interactions. Language \& Communication, 29(4), 366-382. http://dx.doi.org/10.1016/j.langcom.2009.03.001

Tannen, D. (1990). You Just Don't Understand: Women and Men in Conversation. New York: William Morrow.

Williams, C. L. (1995). Still a man's world. Berkeley, CA: University of California.

Wong, F. Y., McCreary, D. R., \& Duffy, K. G. (1990). A further validation of the Bem sex role inventory: A multitrait-multimethod study. Sex Roles, 22(3-4), 249-259. http://dx.doi.org/10.1007/BF00288195

Wood, J. T. (1982). Human communication: A symbolic interactionist perspective. New York: Holt, Rinehart, and Winston.

Wood, J. T. (2001). A critical response to John Gray's Mars and Venus portrayals of men and women. The Southern Communication Journal, 67(2), 201-211. http://dx.doi.org/10.1080/10417940209373229

Wood, J. T. (2005). Gendered lives. Belmont, CA: Wadsworth/Thomson Learning.

Wood, J. T., \& Dindia, K. (1998). What's the difference? A dialogue about differences and similarities between men and women. Mahwah, NJ: Lawrence Erlbaum Associates. 